medRxiv preprint doi: https://doi.org/10.1101/2020.03.03.20030718; this version posted March 6, 2020. The copyright holder for this preprint (which was not certified by peer review) is the author/funder, who has granted medRxiv a license to display the preprint in perpetuity.

It is made available under a CC-BY 4.0 International license .

\title{
Association of public care in childhood with social, criminal, cognitive, and health outcomes in middle-age: six decades of follow-up of members of the 1958 Birth Cohort Study
}

Tiffany H. Xie ${ }^{\text {a,b }}$ (E. tifxie@iu.edu; ORCID: 0000-0002-0572-9760)

G. David Batty, a,c DSc PhD (david.batty@ucl.ac.uk; 0000-0003-1822-5753)

${ }^{a}$ Department of Epidemiology \& Public Health, University College London, London, UK

10 ' Indiana University, Bloomington, USA

$11{ }^{\mathrm{c}}$ School of Biological and Population Health Sciences, Oregon State University, Corvallis, USA

\section{Abstract}

Objectives: To examine if there is an association between childhood public care and adverse life outcomes in middle-age.

Methods: We used data from the United Kingdom 1958 birth cohort study of 18,558 babies.

17 Parents of study members were surveyed at age 7, 11, and 16 years when experience of public care of their offspring was ascertained. An array of outcomes were self-reported by cohort members at age 42 years, and a cognitive test battery was administered at age 50 . Results: 420 (3.8\%) of 11,160 individuals in the analytical sample experienced childhood public care prior to age 16. Net of confounding factors, public care was linked to half of the twentyeight non-mutually exclusive endpoints captured in middle-age with the most consistent effects apparent for psychosocial characteristics: 6/7 sociodemographic, 2/2 anti-social, 3/3 psychological, 1/3 health behaviours, 2/8 somatic health, and $0 / 5$ cognitive. Conclusions: The present study suggests that known associations between childhood care and outcomes in adolescence and early adulthood are also seen in middle-age.

27 Policy implications: Practitioners in health and social services should perhaps more closely 28 monitor care graduates. 
medRxiv preprint doi: https://doi.org/10.1101/2020.03.03.20030718; this version posted March 6, 2020. The copyright holder for this preprint (which was not certified by peer review) is the author/funder, who has granted medRxiv a license to display the preprint in perpetuity.

It is made available under a CC-BY 4.0 International license .

\section{Introduction}

33 Prospective and retrospective cohort studies conducted over several decades have repeatedly

34 demonstrated associations of childhood socioeconomic disadvantage with adult mortality and

35 cardiovascular disease. ${ }^{1,2}$ Such early life adversity has recently been more broadly defined to not

36 only comprise economic hardship but also physical and emotional abuse, nutritional privation,

37 sibling loss, parental separation, and out-of-home care, amongst other characteristics. ${ }^{3}$ Children

38 removed from their home into state care - also referred to as being looked after or public care -

39 are typically placed with a foster family and usually separated from their biological families in

40 order to protect their welfare following parental abuse or neglect, or, less commonly, as a result

41 of their own anti-social behaviour. In recent years there has been a secular rise in the number of

42 children placed in care in both the $\mathrm{US}^{4}$ and the $\mathrm{UK}^{5},{ }^{5}$ with current estimates suggesting up to $4 \%$

43 of the UK population may have experience of pre-adult care.

45 Although public care is predicated upon providing a more nurturing and protective environment

46 for children than available via their family of origin, there is emerging evidence that, in fact,

47 exposure to childhood care is linked to poor outcomes. As such, relative to their unexposed

48 peers, children with a history of public care followed into late adolescence and early adulthood

49 are more likely to experience a greater prevalence of teenage pregnancy, ${ }^{6}$ school exclusion, ${ }^{7}$

50 mental health problems, particularly depression, ${ }^{8,9}$ and substance abuse, ${ }^{7,10}$ and be implicated in

51 criminal activity. ${ }^{9,11}$ These unfavourable outcomes are apparent alongside substantial

52 socioeconomic disadvantage as characterised by poverty, ${ }^{12}$ an absence of health insurance in

53 societies without universal coverage, ${ }^{13}$ low educational attainment, and insecure housing

54 tenure. ${ }^{11}$ Notably, many of these effects appear to hold after taking into account early life 
medRxiv preprint doi: https://doi.org/10.1101/2020.03.03.20030718; this version posted March 6, 2020. The copyright holder for this preprint (which was not certified by peer review) is the author/funder, who has granted medRxiv a license to display the preprint in perpetuity.

It is made available under a CC-BY 4.0 International license .

55 confounding factors including illness and disability, suggesting that the impact of care may be

56 independent of other adverse psychosocial characteristics that tend to prevail at the time of care

57 placement.

59 While it might be anticipated that this array of shorter-term negative life outcomes will position

60 looked after children on a negative life trajectory into middle-age, studies exploring the longer

61 term impact of early life care are very sparse. Most investigators have used a cross-sectional

62 design in which participants were asked to recall care as much as six decades after the

63 experience,,$^{9,11,12,14}$ so raising concerns regarding recall bias. In the only prospective cohort study

64 of which we are aware, economic hardship and mental health problems were associated with

65 prior care exposure in a large cohort of Swedish children resurveyed at age 55 years, ${ }^{15}$ but the

66 impact of care on a broader array of outcomes is untested.

68 We therefore addressed this gap in knowledge using data from a six decade-long follow-up of

69 members of a large British birth cohort study in whom care data was prospectively gathered

70 across childhood. This study also holds information on harmful health behaviours, such as heavy

71 drinking and smoking, psychological problems, anti-social conduct, and, uniquely in the context

72 research on the consequences of care, cognitive function. These data allow us to test the

73 hypothesis that gradients between childhood public care and outcomes apparent in early

74 adulthood will largely extend into middle-age.

75

76 
medRxiv preprint doi: https://doi.org/10.1101/2020.03.03.20030718; this version posted March 6, 2020. The copyright holder for this preprint (which was not certified by peer review) is the author/funder, who has granted medRxiv a license to display the preprint in perpetuity.

It is made available under a CC-BY 4.0 International license .

\section{Methods}

79 We used data from the National Childhood Development Study, also known as the 1958 Birth

80 Cohort Study. ${ }^{16,17}$ An ongoing, closed, prospective cohort study - 11 surveys have been

81 conducted to date - investigators have followed 18,558 births occurring in the United Kingdom

82 during a single week in the late 1950s. In the present analyses we used data from birth to 16

83 years of age to capture public care and potential covariates, while outcomes were assessed at

84 surveys which took place at ages 42 and, for cognitive function only, 50 years. In childhood,

85 participant consent was obtained from parents or caregivers, and, later, the study members

86 themselves. The study was originally approved by the National Health Service Research Ethics

87 Committee and latterly the Multicentre Research Ethics Committee. The present report

88 conforms to STROBE (STrengthening the Reporting of OBservational studies in Epidemiology)

89 guidelines. ${ }^{18}$

91 Assessment of out-of-home care and covariates

92 We ascertained childhood history of public care from prospective surveys conducted when

93 participants were aged 7, 11, and 16 years. Parents were asked: "Has the child been under the

94 care of the local authority, now or in the past?" Study members were regarded has having

95 experienced care in childhood if a positive response was provided to enquiries at any of the three

96 surveys. We derived three indicators of childhood socioeconomic status as recorded at birth:

97 paternal occupational social class as based on the Registrar General's social classification of

98 occupations (6 levels), ${ }^{19}$ maternal education level denoted by age at leaving full-time educations

99 (in the era of data collection, school was mandatory until age 15 years), and number of persons

100 in the household. Indicators of childhood health, recorded at age 7, included hospital visits for 
medRxiv preprint doi: https://doi.org/10.1101/2020.03.03.20030718; this version posted March 6, 2020. The copyright holder for this preprint (which was not certified by peer review) is the author/funder, who has granted medRxiv a license to display the preprint in perpetuity.

It is made available under a CC-BY 4.0 International license .

101 illnesses or medical tests, any disability (including birth defects, visual/hearing/speech handicaps,

102 epilepsy, and asthma), and internalizing and externalizing symptoms, as quantified using the

103 Bristol Social Adjustment Guides. ${ }^{20,21}$ Summary scores were created for the internalizing

104 symptoms of unforthcomingness, withdrawal, depression, and miscellaneous symptoms, and for

105 the externalizing symptoms of anxiety for acceptance by adult or peers, hostility towards adults,

106 restlessness, and inconsequential behaviour. Remaining covariates were maternal age at birth of

107 study member and maternal marital status at birth (married, separated, divorced, widowed, stable

108 union, and unmarried).

\section{Assessment of adult outcomes}

111 All adult characteristics were self-reported. At age 42, we assessed occupational social class (as

112 above), unemployment, receipt of any social benefits by the participant or their partner,

113 educational attainment, cohabitation, marital status, and history of homelessness (since age 33

114 years). Indicators of anti-social behaviour were use of illegal drugs in the past year and having

115 received a criminal conviction (since age 33 years). We quantified psychological distress using

116 the Malaise Inventory. ${ }^{22}$ Validated in the general population, including the present sample, ${ }^{23}$ this

117 is a 24 -item scale in which a score of $\geq 7$ has been used to indicate morbidity. In addition to the

118 reporting of symptoms, diagnosis was captured using enquiries about being under the care of a

119 medical specialist for depression or being hospitalised in the past year for its treatment. Alcohol

120 problems were assessed using the CAGE ('Cutting down, Annoyance by Criticism, Guilty

121 feeling, and Eye-openers') Questionnaire. This is also validated screening instrument where a

122 score of $\geq 2$ indicates possible alcohol dependence or abuse, ${ }^{24,25}$ a threshold that has been shown

123 to have predictive capacity for mortality. ${ }^{26}$ 
medRxiv preprint doi: https://doi.org/10.1101/2020.03.03.20030718; this version posted March 6, 2020. The copyright holder for this preprint (which was not certified by peer review) is the author/funder, who has granted medRxiv a license to display the preprint in perpetuity.

It is made available under a CC-BY 4.0 International license .

125 Current smoking was based on standard enquiries. For alcohol intake, study members were

126 asked how many drinks they had consumed in the past 7 days, including beer, wine, spirits,

127 sherry, 'alcopops', and any other alcoholic drinks. Heavy drinking was denoted by exceeding

128 specific thresholds for women (>35 drinks/week) and men (>50). Participants were asked how

129 often they take part in any physical activity with low levels being defined by exercising fewer

130 than 3 times a week. ${ }^{27}$ Obesity was denoted by a body mass index of $\geq 30 \mathrm{~kg} / \mathrm{m}^{2}$ as derived from

131 self-reported height and weight. ${ }^{28}$ Study members reported a physician diagnosis of diabetes and

132 high blood pressure. Other health indices included physical disability - denoted by permanent

133 illness or injury for six or more months - accidents (since age 33 years), hospital admissions,

134 occurrence of any cancer, and general health. General health was rated on a standard four-point

135 scale (excellent, good, fair, or poor). Accidents were defined as events such as road- or sports-

136 related injury, sexual assault, or muggings that required medical attention.

137

138 Lastly, cognitive function at age 50 was measured with a battery of memory and executive

139 functioning tests which have been widely used in other population-based surveys. ${ }^{29}$ Memory

140 was assessed by a test which involved memorising words with immediate and delayed recall.

141 Executive functioning was measured by letter cancellation and animal naming tasks.

\section{Statistical analysis}

144 We used odds ratios with accompanying confidence intervals, computed using logistic regression,

145 to summarise the relationship between childhood care and outcomes at age 42 years, while linear

146 regression models produced beta coefficients, also with $95 \%$ confidence intervals, to quantify the 
medRxiv preprint doi: https://doi.org/10.1101/2020.03.03.20030718; this version posted March 6, 2020. The copyright holder for this preprint (which was not certified by peer review) is the author/funder, who has granted medRxiv a license to display the preprint in perpetuity.

It is made available under a CC-BY 4.0 International license .

147 relationship between care and indicators of cognitive function at 50 years. For all endpoints,

148 effect estimates were first adjusted for sex and then for a series of covariates which characterised

149 the early life socio-demographic and health circumstances of the study member; as a birth cohort

150 study, controlling for age was not required. All data analyses were conducted using Stata SE

151 (Version 15.1, College Station, TX: StataCorp).

153 Results

154 In Figure 1 we show the flow of study members into the analytical sample. In total, care history 155 data across childhood were available for 16,583 study members; of these, 11,160 participated in

156 the survey at age 42 and 9578 in the resurvey at age 50 years. Those study members who did not

157 take part in the age 42 sweep were somewhat more likely to have experienced care in pre-

158 adulthood $(5.6 \%)$ than participants $(3.8 \%)$. The same observations were made at age 50 .

160 In Table 1, we present study member early life characteristics according to history of childhood

161 care contingent upon participation in the survey at age 42 years. In this analytical sample, 420

$162(3.8 \%)$ had a history of care before age 16. In general, children who had a history of being in

163 public care had markedly less favourable characteristics relative to their unexposed peers. Thus,

164 exposed children were more likely to come from socioeconomically disadvantaged backgrounds

165 as evidenced by a greater prevalence of overcrowding, manual paternal social class, and lower

166 maternal education. Similarly, such children had a higher health burden based on hospital visits,

167 disability, and internalizing and externalizing symptoms, the latter differences being particularly

168 marked. Given the clear patterning of early life characteristics according to public care exposure,

169 we incorporated these factors as confounders in the following multivariable regression models in 
medRxiv preprint doi: https://doi.org/10.1101/2020.03.03.20030718; this version posted March 6, 2020. The copyright holder for this preprint (which was not certified by peer review) is the author/funder, who has granted medRxiv a license to display the preprint in perpetuity.

It is made available under a CC-BY 4.0 International license .

170 which we attempted to ascertain the independent relation, if any, between childhood care and

171 adult outcomes.

172

173 In Table 2 we depict the association of experience of public care with sociodemographic, anti-

174 social, and psychological outcomes at age 42 years. Following adjustment for sex, individuals

175 with a history of childhood care were more than twice as likely to be in a manual social class, be

176 unemployed, be in receipt of social benefits, have only a basic education, and have experienced

177 homelessness in adulthood compared to unexposed individuals. Children from a care

178 background were also markedly more likely to live alone several decades later, though there was

179 no apparent link with marital status. Separate control for potential confounding factors from

180 early life, particularly poverty rather than indices of health, led to partial attenuation for some but

181 not all associations of childhood care with adult outcomes. Statistical significance at

182 conventional levels was typically retained, however, as evident by the absence of unity in the

183 accompanying confidence intervals.

185 Compared to participants who had not been in public care, those with such a history were more 186 likely to engage in delinquency in middle-age, as evidenced by a doubling of risk of illicit drug

187 use and a criminal conviction. While taking into account early social circumstances diminished 188 the magnitude of effects for criminality, this was not the case for drug use.

190 Participants with a history of care were more than twice as likely as those without to have had a

191 diagnosis of adult depression, as denoted by being under the care of a specialist and/or being

192 hospitalised. Notably, while controlling for socioeconomic position in childhood led to some 
medRxiv preprint doi: https://doi.org/10.1101/2020.03.03.20030718; this version posted March 6, 2020. The copyright holder for this preprint (which was not certified by peer review) is the author/funder, who has granted medRxiv a license to display the preprint in perpetuity.

It is made available under a CC-BY 4.0 International license.

193 attenuation of these odds ratio but this was not the case after taking into account childhood

194 distress, amongst other health characteristics. The care-alcohol problems relationship was more

195 marked than for drinking behaviour (Table 3). Indeed, with the exception of cigarette smoking,

196 where a doubling in prevalence was apparent in adults who, as children, had been looked after,

197 the health behaviours of alcohol consumption and physical exertion were not strongly linked to

198 care status.

199

200 Individuals with a history of care were almost three times as likely to experience physical

201 disability in adulthood compared to individuals without such a background. These individuals

202 were also more likely to report poor general health and cancer from all sites combined. There

203 were no clear link between pre-adult care and later obesity and, perhaps as a result, relationships

204 with adult diabetes and hypertension were not apparent.

205

206 In Figure 2 we show the results from the multivariable models in which we adjust the

207 association between care and adult outcomes for sex, sociodemographic and health covariates

208 from childhood. Most of the socioeconomic outcomes were robust to such statistical treatment.

209 Other endpoints which were also related to public care based on these more complex models

210 included adult mental health, illicit drug use, smoking, disability and poor self-rated health.

211

212 We also examined if being looked after in early life was related to cognitive function at age 50

213 years (Table 4). The mean difference in performance on 5 tests according to care status was

214 modest. With the exception of letter cancellation speed, an indicator of sustained concentration,

215 these differences were apparent after sex-adjustment but were largely lost after control for 
medRxiv preprint doi: https://doi.org/10.1101/2020.03.03.20030718; this version posted March 6, 2020. The copyright holder for this preprint (which was not certified by peer review) is the author/funder, who has granted medRxiv a license to display the preprint in perpetuity.

It is made available under a CC-BY 4.0 International license .

216 multiple potential confounding factors. Lastly, when we repeated all our analyses based on

217 individuals without missing data, our conclusions were largely unchanged for both non-cognitive

218 (Supplemental Table 1) and cognitive outcomes (Supplemental Table 2).

220 Discussion

221 The main findings of this study were that a history of public care during childhood was

222 associated with a broad range of negative outcomes in adulthood, most consistently

223 socioeconomic factors and anti-social behaviour. That is, after multivariable adjustment and at

224 conventional levels of statistical significance, public care was linked to half of the thirty

225 endpoints featured in the present analyses, comprising 6/7 sociodemographic, 2/2 anti-social, 3/5

226 psychological, 1/3 health behaviours, 2/8 somatic health, and 0/5 cognitive.

228 While these findings may be important given the pernicious nature of several of the outcomes in

229 their own right, they may also offer insights into the observation that, relative to the general

230 population and net of confounding, children who are exposure to care may experience up to three

231 times the rate of premature mortality by middle-age. ${ }^{30-32}$ This observation raises the question of

232 how exposure to public care in childhood is embodied, in turn elevating mortality. In analyses of

233 two cohort studies, we have recently shown little evidence of an association between pre-adult

234 public care and various adult cardiovascular, inflammatory, neuroendocrine, and respiratory risk

235 markers for mortality. ${ }^{33,34}$ While the present results suggest that, instead, the impact of public

236 care on death may be via social circumstances and potentially some indicators of health, our

237 study sample is insufficiently mature to enable us to simultaneously run analyses in which we

238 incorporate data on exposure, potential mediators, and mortality risk. In the only study of which 
medRxiv preprint doi: https://doi.org/10.1101/2020.03.03.20030718; this version posted March 6, 2020. The copyright holder for this preprint (which was not certified by peer review) is the author/funder, who has granted medRxiv a license to display the preprint in perpetuity.

It is made available under a CC-BY 4.0 International license .

239 we are aware to have done so, indices of socio-economic position and mental health appear to

240 have some explanatory role in the public care-mortality relationship. ${ }^{35}$ Replication and testing

241 using a wider range of potential mediating characteristics, such as somatic health, health

242 behaviours and criminality as identified herein, is now required.

\section{Comparison with existing studies}

245 Our results of a wide-ranging association of pre-adult care with outcomes in middle-age broadly

246 accord with evidence from samples drawn from Scandinavia, ${ }^{8} \mathrm{US}^{12}{ }^{12}$ and $\mathrm{UK}^{9}$ populations

247 followed earlier in the adult life course. Our findings also seem to corroborate those from cross-

248 sectional studies including older-aged groups that relied on distant recall of early life care., ${ }^{9,11,12,14}$

250 In the present analyses, while childhood care was associated with a higher burden of mental

251 health problems there were less consistent relationships with health behaviours and somatic

252 health outcomes. Thus, our findings support analyses of data from the 1970 British birth cohort

253 which found associations between care history and smoking, but not alcohol problems or

254 physical exertion. ${ }^{36}$ We did not find associations between care history and either high blood

255 pressure or obesity, although these are not universal observations. ${ }^{13,14}$

257 To our knowledge, ours was the first study to explore the influence of being looked after in

258 childhood on cognition in mid-life. With both care ${ }^{33}$ and cognition ${ }^{37}$ being strongly socially

259 patterned, we anticipated that care would be related to lower cognitive performance but this was

260 not the case - even after basic adjustment, the difference in performance on various tests of

261 mental ability according to care status was marginal. 
medRxiv preprint doi: https://doi.org/10.1101/2020.03.03.20030718; this version posted March 6, 2020. The copyright holder for this preprint (which was not certified by peer review) is the author/funder, who has granted medRxiv a license to display the preprint in perpetuity.

It is made available under a CC-BY 4.0 International license .

\section{Study strengths and limitations}

264 The strengths of our study include the well-characterised study participants, the prospective

265 measurement of public care across childhood as opposed to distant recall in older age, and our

266 use of an extensive range of outcomes which, unusually in the context of the present literature,

267 allowed us to compare effects within a single population. Our study is of course not without

268 several limitations. First, 59\% of cohort members with care data took part in the resurvey at age

26942 (51\% at age 50 years), with, as shown, lower participation rates in individuals with such a

270 history. Provided there was still sufficient variation in exposure and outcomes in the remaining

271 study members, and given that our objective was to explore relationships as opposed to

272 examining the prevalence of a given characteristic, attrition should not have impacted upon our

273 findings. ${ }^{38,39}$ Second, parents may provide a socially desirable response to an enquiry as

274 revealing and sensitive as the public care history of their offspring. While we are unaware of any

275 studies assessing the agreement of parental self-reported care with a gold standard such as

276 administrative data, in preliminary findings from a meta-analysis of studies of childhood care

277 exposure and adult mortality risk in which we compared the predictive value of care data as

278 ascertained from parental report with electronic records across studies, we found that care data

279 collected using each mode were associated with around a doubling of adult mortality rates in

280 those with a history of care relative to those without. ${ }^{40}$ This suggests similar predictive validity

281 for self-reported and administrative data. Outcome data were also self-reported, on this occasion

282 by the study members as opposed to parents, but many of these have been shown to sufficiently

283 valid for the purposes of epidemiological investigation. 
medRxiv preprint doi: https://doi.org/10.1101/2020.03.03.20030718; this version posted March 6, 2020. The copyright holder for this preprint (which was not certified by peer review) is the author/funder, who has granted medRxiv a license to display the preprint in perpetuity.

It is made available under a CC-BY 4.0 International license .

Third, vulnerable children and families are hard to reach in a research context, and it is likely

286 that the present study will not capture data on people who experienced the more challenging of

287 upbringings. For that, purposeful sampling of such groups would be required alongside

288 unexposed children to facilitate comparison. Fourth, we were unable to examine potentially

289 important care placement characteristics, including the impact of duration, type, reason, or

290 stability. Fifth, although we attempted to take into account the early life circumstances of

291 children experiencing care, it is not possible to completely separate the impact of the various

292 adversities experienced prior to and during care. Finally, the public care system in the UK has

293 evolved in the several decades since the present study members were children. Some changes,

294 most obviously the establishment of the modern UK protection system in 1973, have seemingly

295 improved the circumstances for this disadvantaged population such that they now receive

296 intervention earlier and experience less placement instability. ${ }^{41}$ While this raises the possibility

297 that the apparent longer-term negative effects may be diminished for children in

298 contemporaneous care, there is in fact evidence that more recent generations of children in foster

299 care still experience subsequent adversity. ${ }^{13,42}$

$301 \quad$ Public health implications and future research directions

302 Taken together with the findings of other observational studies, there is growing evidence of risk

303 in multiple domains across the adult life course for people exposure to childhood care. As with

304 all potential population-based interventions, similarly consistent experimental evidence must

305 now be accumulated in order to inform public policy. Our results and those of other groups are

306 likely to be informative for the planning and implementation of trials, ideally randomised with

307 control groups. Given the logistical and financial implications of such an endeavour, however, 
medRxiv preprint doi: https://doi.org/10.1101/2020.03.03.20030718; this version posted March 6, 2020. The copyright holder for this preprint (which was not certified by peer review) is the author/funder, who has granted medRxiv a license to display the preprint in perpetuity.

It is made available under a CC-BY 4.0 International license.

308 quasi experimental studies which utilise changes in child protection legislation as an instrumental

309 variable may also have value. In the meantime, practitioners in health and social care should

310 perhaps more closely monitor care graduates.

311

312 Conclusions

313 This study adds to a growing body of evidence of the shorter-term negative impact of public care

314 in childhood on a broad range of outcomes to suggest that many effects extend further into the

315 adult life course than previously understood.

316 
medRxiv preprint doi: https://doi.org/10.1101/2020.03.03.20030718; this version posted March 6, 2020. The copyright holder for this preprint (which was not certified by peer review) is the author/funder, who has granted medRxiv a license to display the preprint in perpetuity.

It is made available under a CC-BY 4.0 International license.

317 Correspondence: David Batty, Department of Epidemiology \& Public Health, University

318 College London, 1-19 Torrington Place, London, UK, WC1E 6BT. E. david.batty@ucl.ac.uk

320 Acknowledgements: GDB is supported by the UK Medical Research Council (MR/P023444/1)

321 and the US National Institute on Aging (1R56AG052519-01; 1R01AG052519-01A1). CdM was

322 supported by the Swiss National Science Foundation when this work was initiated.

324 Conflict of interest: None to declare.

Human participant protection: Participant consent was obtained throughout the study from

327 parents or caregivers, and, later, the study members themselves. The study was originally

328 approved by the National Health Service Research Ethics Committee and latterly the Multicentre 329 Research Ethics Committee.

331 Contributions: Tiffany Xie analysed the data, interpreted the results, and jointly drafted the

332 manuscript. Carlos de Mestral built the dataset, interpreted the results, and revised the

333 manuscript. David Batty generated the idea for the study, formulated an analytical plan,

334 interpreted the results, and jointly drafted the manuscript. All authors approved the final version 335 of the manuscript.

337 Manuscript statistics: 3341 words (excluding abstract 185 words), 42 references, 4 tables (2

338 supplemental tables), 2 figures 
medRxiv preprint doi: https://doi.org/10.1101/2020.03.03.20030718; this version posted March 6, 2020. The copyright holder for this preprint (which was not certified by peer review) is the author/funder, who has granted medRxiv a license to display the preprint in perpetuity.

It is made available under a CC-BY 4.0 International license .

\section{References}

1. Galobardes B, Lynch JW, Davey Smith G. Childhood socioeconomic circumstances and cause-specific mortality in adulthood: systematic review and interpretation. Epidemiologic reviews 2004; 26: 7-21.

2. Batty GD, Der G, MacIntyre S, Deary IJ. Does IQ explain socioeconomic inequalities in health? Evidence from a population based cohort study in the west of Scotland. BMJ 2006; 332(7541): 580-4.

3. Hughes K, Bellis MA, Hardcastle KA, et al. The effect of multiple adverse childhood experiences on health: a systematic review and meta-analysis. Lancet Public Health 2017; 2(8): e356-e66.

4. US Department of Health and Human Services - Children's Bureau. The Adoption and Foster Care Analysis and Reporting System Report No. 25 (https://www.acf.hhs.gov/cb accessed January 20, 2019); 2018.

5. UK Department of Education. Children Looked after in England Including Adoption: 2017 to 2018

(https://assets.publishing.service.gov.uk/government/uploads/system/uploads/attachment_da ta/file/757922/Children_looked_after_in_England_2018_Text_revised.pdf - accessed January 20, 2019.).

6. Vinnerljung B, Franzen E, Danielsson M. Teenage parenthood among child welfare clients: a Swedish national cohort study of prevalence and odds. J Adolesc 2007; 30(1): 97-116.

7. Viner RM, Taylor B. Adult Health and Social Outcomes of Children Who Have Been in Public Care: Population-Based Study. Pediatrics 2005; 115(4): 894-9.

8. Buchanan A, Ten Brinke J, Flouri E. Parental background, social disadvantage, public "care," and psychological problems in adolescence and adulthood. J Am Acad Child Adolesc Psychiatry 2000; 39(11): 1415-23.

9. Dregan A, Gulliford MC. Foster care, residential care and public care placement patterns are associated with adult life trajectories: population-based cohort study. Soc Psychiatry Psychiatr Epidemiol 2012; 47(9): 1517-26.

10. Cote SM, Orri M, Marttila M, Ristikari T. Out-of-home placement in early childhood and psychiatric diagnoses and criminal convictions in young adulthood: a population-based propensity score-matched study. Lancet Child Adolesc Health 2018; 2(9): 647-53.

11. Teyhan A, Wijedasa D, Macleod JJBo. Adult psychosocial outcomes of men and women who were looked-after or adopted as children: prospective observational study. 2018; 8(2): e019095.

12. Zlotnick C, Tam TW, Soman LA. Life course outcomes on mental and physical health: the impact of foster care on adulthood. Am J Public Health 2012; 102(3): 534-40.

13. Ahrens KR, Garrison MM, Courtney ME. Health outcomes in young adults from foster care and economically diverse backgrounds. Pediatrics 2014; 134(6): 1067-74.

14. Schneider R, Baumrind N, Pavao J, et al. What happens to youth removed from parental care?: Health and economic outcomes for women with a history of out-of-home placement. Children and Youth Services Review 2009; 31(4): 440-4.

15. Brannstrom L, Forsman H, Vinnerljung B, Almquist YB. The truly disadvantaged? Midlife outcome dynamics of individuals with experiences of out-of-home care. Child Abuse Negl 2017; 67: 408-18. 
medRxiv preprint doi: https://doi.org/10.1101/2020.03.03.20030718; this version posted March 6, 2020. The copyright holder for this preprint (which was not certified by peer review) is the author/funder, who has granted medRxiv a license to display the preprint in perpetuity.

It is made available under a CC-BY 4.0 International license .

16. Power C, Elliott J. Cohort profile: 1958 British birth cohort (National Child Development Study). Int J Epidemiol 2006; 35(1): 34-41.

17. Batty GD, Ploubidis GB, Goodman A, Bann D. Association of nursery and early school attendance with later health behaviours, biomedical risk factors, and mortality: evidence from four decades of follow-up of participants in the 1958 birth cohort study. J Epidemiol Community Health 2018; 72(7): 658-63.

18. von Elm E, Altman DG, Egger M, et al. The Strengthening the Reporting of Observational Studies in Epidemiology (STROBE) statement: guidelines for reporting observational studies. Lancet 2007; 370(9596): 1453-7.

19. General R. The Registrar General's Decennial Supplement, England and Wales 1961, Occupational Mortality Tables. London: HMSO; 1971.

20. Clark C, Rodgers B, Caldwell T, Power C, Stansfeld S. Childhood and adulthood psychological ill health as predictors of midlife affective and anxiety disorders: the 1958 British Birth Cohort. Arch Gen Psychiatry 2007; 64(6): 668-78.

21. Stott DH, Sykes EG, Marston N. The social adjustment of children: manual of the British social-adjustment guides: Hodder \& Stoughton; 1974.

22. Rutter M, Tizard J. Education, health and behaviour. London: Longman; 1970.

23. Rodgers B, Pickles A, Power C, Collishaw S, Maughan B. Validity of the Malaise Inventory in general population samples. Soc Psychiatry Psychiatr Epidemiol 1999; 34(6): 333-41.

24. King M. At risk drinking among general practice attenders: validation of the CAGE questionnaire. Psychol Med 1986; 16(1): 213-7.

25. Buchsbaum DG, Buchanan RG, Centor RM, Schnoll SH, Lawton MJ. Screening for alcohol abuse using CAGE scores and likelihood ratios. Ann Intern Med 1991; 115(10): 774-7.

26. Batty GD, Hunt K, Emslie C, Lewars H, Gale CR. Alcohol problems and all-cause mortality in men and women: predictive capacity of a clinical screening tool in a 21-year follow-up of a large, UK-wide, general population-based survey. J Psychosom Res 2009; 66(4): 317-21.

27. Winning A, McCormick MC, Glymour MM, Gilsanz P, Kubzansky LD. Childhood Psychological Distress and Healthy Cardiovascular Lifestyle 17-35 Years Later: The Potential Role of Mental Health in Primordial Prevention. Ann Behav Med 2018; 52(8): 62132.

28. Organization WH. Obesity: Preventing and Managing the Global Epidemic (Technical Report Series 894). Geneva: WHO; 2000.

29. Bowling A, Pikhartova J, Dodgeon B. Is mid-life social participation associated with cognitive function at age 50? Results from the British National Child Development Study (NCDS). BMC Psychol 2016; 4(1): 58.

30. Gao M, Brannstrom L, Almquist YB. Exposure to out-of-home care in childhood and adult all-cause mortality: a cohort study. Int J Epidemiol 2017; 46(3): 1010-7.

31. Kalland M, Pensola TH, Merilainen J, Sinkkonen J. Mortality in children registered in the Finnish child welfare registry: population based study. Bmj 2001; 323(7306): 207-8.

32. Vinnerljung B, Ribe MJIJoSW. Mortality after care among young adult foster children in Sweden. 2001; 10(3): 164-73.

33. de Mestral C, Bell S, Hamer M, Batty GD. Out-of-home care in childhood and biomedical risk factors in middle-age: National birth cohort study. Am J Hum Biol 2019: e23343.

34. Batty GD, Hamer M. Public care during childhood and biomedical risk factors in middle-age: the 1970 birth cohort study. Am J Epidemiol In press. 
medRxiv preprint doi: https://doi.org/10.1101/2020.03.03.20030718; this version posted March 6, 2020. The copyright holder for this preprint (which was not certified by peer review) is the author/funder, who has granted medRxiv a license to display the preprint in perpetuity.

It is made available under a CC-BY 4.0 International license .

35. Almquist YB, Brannstrom L. Do trajectories of economic, work- and health-related disadvantages explain child welfare clients' increased mortality risk? A prospective cohort study. BMC Public Health 2019; 19(1): 418.

36. Dregan A, Brown J, Armstrong D. Do adult emotional and behavioural outcomes vary as a function of diverse childhood experiences of the public care system? Psychol Med 2011; 41(10): 2213-20.

37. Neisser U, Boodoo G, Bouchard Jnr T, et al. Intelligence: knowns and unknowns. Am Psychol 1996; 51: 77-101.

38. Batty GD, Shipley M, Tabak A, et al. Generalizability of occupational cohort study findings. Epidemiology 2014; 25(6): 932-3.

39. Batty GD, Gale CR. Impact of resurvey non-response on the associations between baseline risk factors and cardiovascular disease mortality: prospective cohort study. J Epidemiol Community Health 2009; 63(11): 952-5.

40. de Mestral C, Bell S, Batty GD. Public care in childhood, risk factors in adulthood, and mortality: a pooled date from two birth cohorts (Parallel sessions - A6_1, https://sphc.ch/de/vergangene-konferenzen/sphc-2018/sessions/). Swiss Public Health Conference 2018; Neuchatel, Switzerland; 2018.

41. Mc Grath-Lone L, Dearden L, Nasim B, Harron K, Gilbert R. Changes in first entry to outof-home care from 1992 to 2012 among children in England. Child Abuse Negl 2016; 51: 163-71.

42. Pecora PJ, Kessler RC, O'Brien K, et al. Educational and employment outcomes of adults formerly placed in foster care: Results from the Northwest Foster Care Alumni Study. Children and youth services review 2006; 28(12): 1459-81. 
medRxiv preprint doi: https://doi.org/10.1101/2020.03.03.20030718; this version posted March 6, 2020. The copyright holder for this preprint (which was not certified by peer review) is the author/funder, who has granted medRxiv a license to display the preprint in perpetuity.

It is made available under a CC-BY 4.0 International license .

Table 1. Early life characteristics of study members according to history of childhood care, 459

\begin{tabular}{|l|c|c|c|}
\hline & $\begin{array}{c}\text { No history } \\
\text { of care } \\
(\mathbf{N = 1 0 , 7 4 0 )}\end{array}$ & $\begin{array}{c}\text { History } \\
\text { of care } \\
(\mathbf{N}=\mathbf{4 2 0})\end{array}$ & $\begin{array}{c}\text { p-value for } \\
\text { difference }\end{array}$ \\
\hline Child characteristics & $\mathbf{N}(\mathbf{\%})$ & $\mathbf{N}(\mathbf{\%})$ & \\
\hline Female & $5440(50.65)$ & $218(51.90)$ & 0.614 \\
\hline Overcrowding & $1337(14.36)$ & $97(30.22)$ & $<0.001$ \\
\hline Hospital visit & $1109(11.68)$ & $58(16.52)$ & 0.006 \\
\hline Disabled & $1076(10.79)$ & $56(14.21)$ & 0.033 \\
\hline High internalizing symptoms & $1794(18.49)$ & $99(27.05)$ & $<0.001$ \\
\hline High externalizing symptoms & $1956(20.16)$ & $137(37.43)$ & $<0.001$ \\
\hline Family characteristics & & & \\
\hline Father manual social class & $7198(70.95)$ & $327(86.05)$ & $<0.001$ \\
\hline Mother's age at birth (mean, SD) & $27.56(5.64)$ & $26.17(5.92)$ & $<0.0001$ \\
\hline Mother married & $9959(97.32)$ & $314(78.11)$ & $<0.001$ \\
\hline Low maternal education & $7517(73.65)$ & $333(83.25)$ & $<0.001$ \\
\hline
\end{tabular}

Overcrowding was denoted by 6 or more persons in the household. High internalising symptoms were defined by a 
Table 2. Association of care in childhood with sociodemographic, anti-social, and psychological outcomes at age 42 years, 1958 Birth Cohort Study

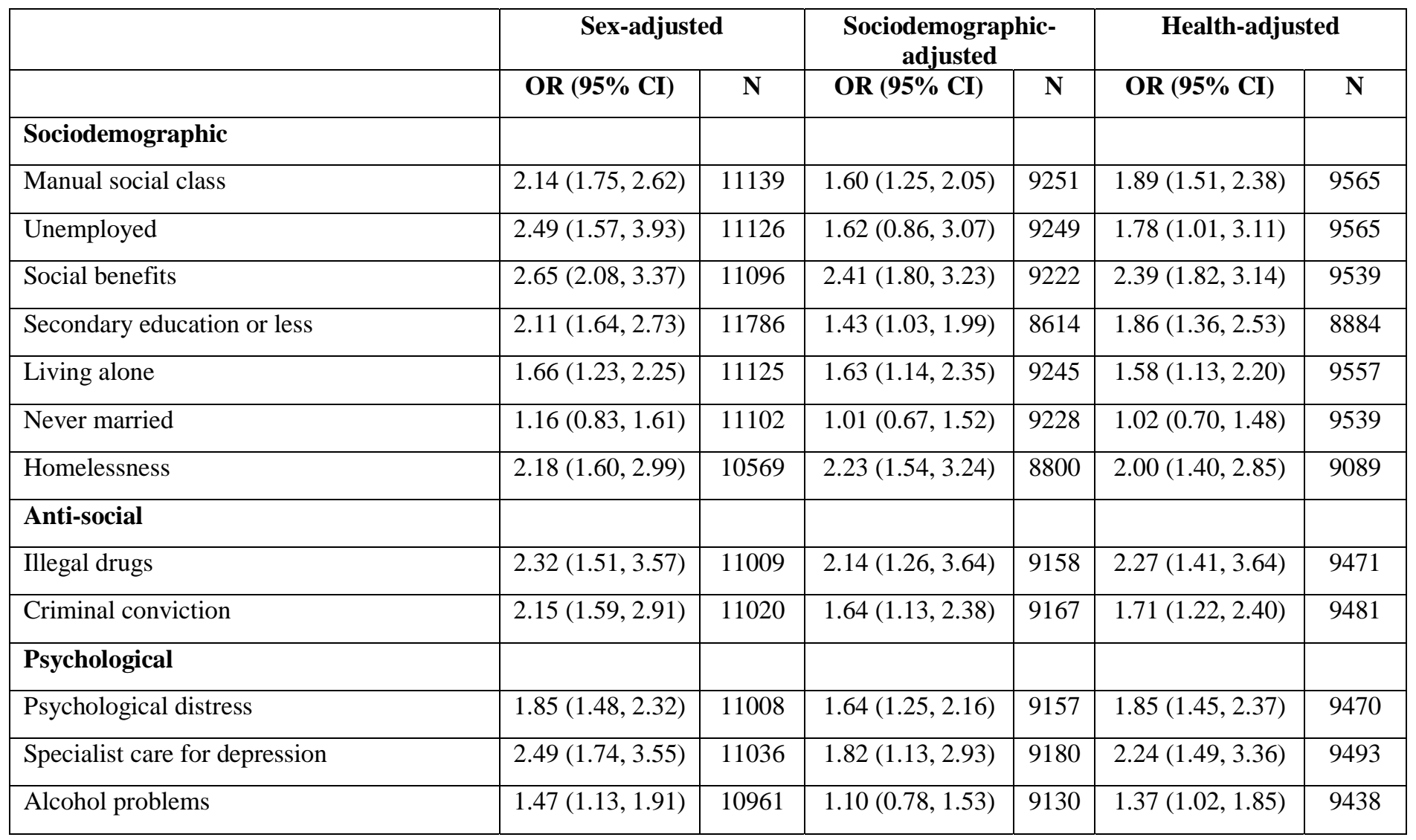

OR, odds ratio. Sociodemographic-adjusted odds ratios are adjusted for sex plus parental social class, mother's age at birth, mother's marital status, mother's education, and high number of people in household. Health-adjusted odds ratios are adjusted for sex plus childhood hospitalizations, childhood disability, and internalizing and externalizing symptoms. 
Table 3. Association of care in childhood with health behaviours and somatic health outcomes at age 42 years, 1958 Birth Cohort Study

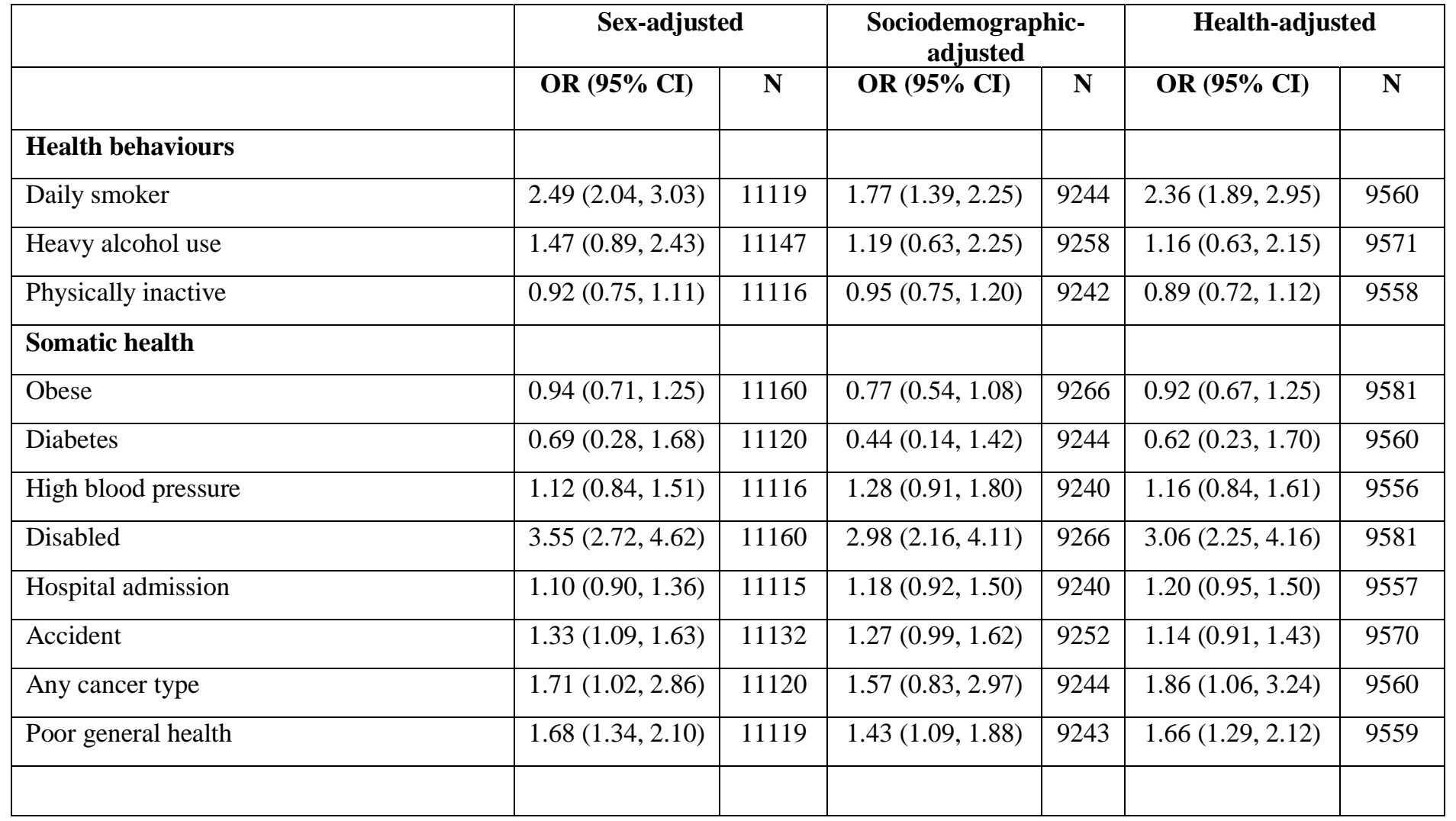

OR, odds ratio. Sociodemographic-adjusted odds ratios are adjusted for sex plus parental social class, mother's age at birth, mother's marital status, mother's education, and high number of people in household. Health-adjusted odds ratios are adjusted for sex plus childhood hospitalizations, childhood disability, and internalizing and externalizing symptoms. 
Table 4. Association of care in childhood with cognitive function at age $50 \mathrm{y}$,

\section{Birth Cohort Study}

\begin{tabular}{|c|c|c|c|c|c|c|c|c|c|c|}
\hline & \multirow{2}{*}{$\begin{array}{c}\begin{array}{c}\text { No history of } \\
\text { care }\end{array} \\
\text { Mean (SD) }\end{array}$} & \multirow{2}{*}{$\begin{array}{c}\begin{array}{c}\text { History of } \\
\text { Care }\end{array} \\
\text { Mean (SD) }\end{array}$} & \multicolumn{2}{|l|}{ Sex-adjusted } & \multicolumn{2}{|c|}{$\begin{array}{c}\text { Sociodemographic- } \\
\text { adjusted }\end{array}$} & \multicolumn{2}{|c|}{ Health-adjusted } & \multicolumn{2}{|c|}{ Multiply-adjusted } \\
\hline & & & B $(95 \%$ CI $)$ & $\mathbf{N}$ & B $(95 \% \mathrm{CI})$ & $\mathbf{N}$ & B $(95 \% \mathrm{CI})$ & $\mathbf{N}$ & B $(95 \% \mathrm{CI})$ & $\mathbf{N}$ \\
\hline Letter Cancellation Accuracy & $21.65(5.87)$ & $20.90(6.50)$ & $-0.81(-1.45,-0.16)$ & 9243 & $-0.89(-1.67,-0.10)$ & 7705 & $-0.75(-1.48,-0.02)$ & 7953 & $-0.83(-1.64,-0.03)$ & 7405 \\
\hline Letter Cancellation Speed & $334.39(88.41)$ & $330.01(98.33)$ & $-5.1(-14.79,4.59)$ & 9243 & $-8.25(-20.08,3.58)$ & 7705 & $-6.13(-17.18,4.92)$ & 7953 & $-9.28(-21.49,2.93)$ & 7405 \\
\hline Animal Naming & $22.29(6.29)$ & $21.41(6.51)$ & $-0.88(-1.57,-0.20)$ & 9444 & $0.06(-0.76,0.87)$ & 7870 & $-0.53(-1.29,0.23)$ & 8120 & $0.23(-0.60,1.07)$ & 7561 \\
\hline Word Recall Immediate & $6.56(1.49)$ & $6.23(1.47)$ & $-0.33(-0.49,-0.17)$ & 9444 & $-0.17(-0.36,0.03)$ & 7870 & $-0.20(-0.38,-0.02)$ & 8120 & $-0.12(-0.32,0.08)$ & 7561 \\
\hline Word Recall Delayed & $5.43(1.84)$ & $5.01(1.88)$ & $-0.43(-0.63,-0.24)$ & 9388 & $-0.22(-0.46,0.02)$ & 7823 & $-0.29(-0.51,-0.07)$ & 8071 & $-0.15(-0.39,0.10)$ & 7514 \\
\hline
\end{tabular}

B, beta coefficient. Sociodemographic-adjusted odds ratios are adjusted for sex plus parental social class, mother's age at birth, mother's marital status, mother's education, and high number of people in household. Health-adjusted odds ratios

are adjusted for sex plus childhood hospitalizations, childhood disability, and internalizing and externalizing symptoms.

Multiply-adjusted odds ratios are adjusted for all these covariates. 
Figure 1. Flow of study members through phases of data collection into the present analytical sample, 1958 Birth Cohort Study

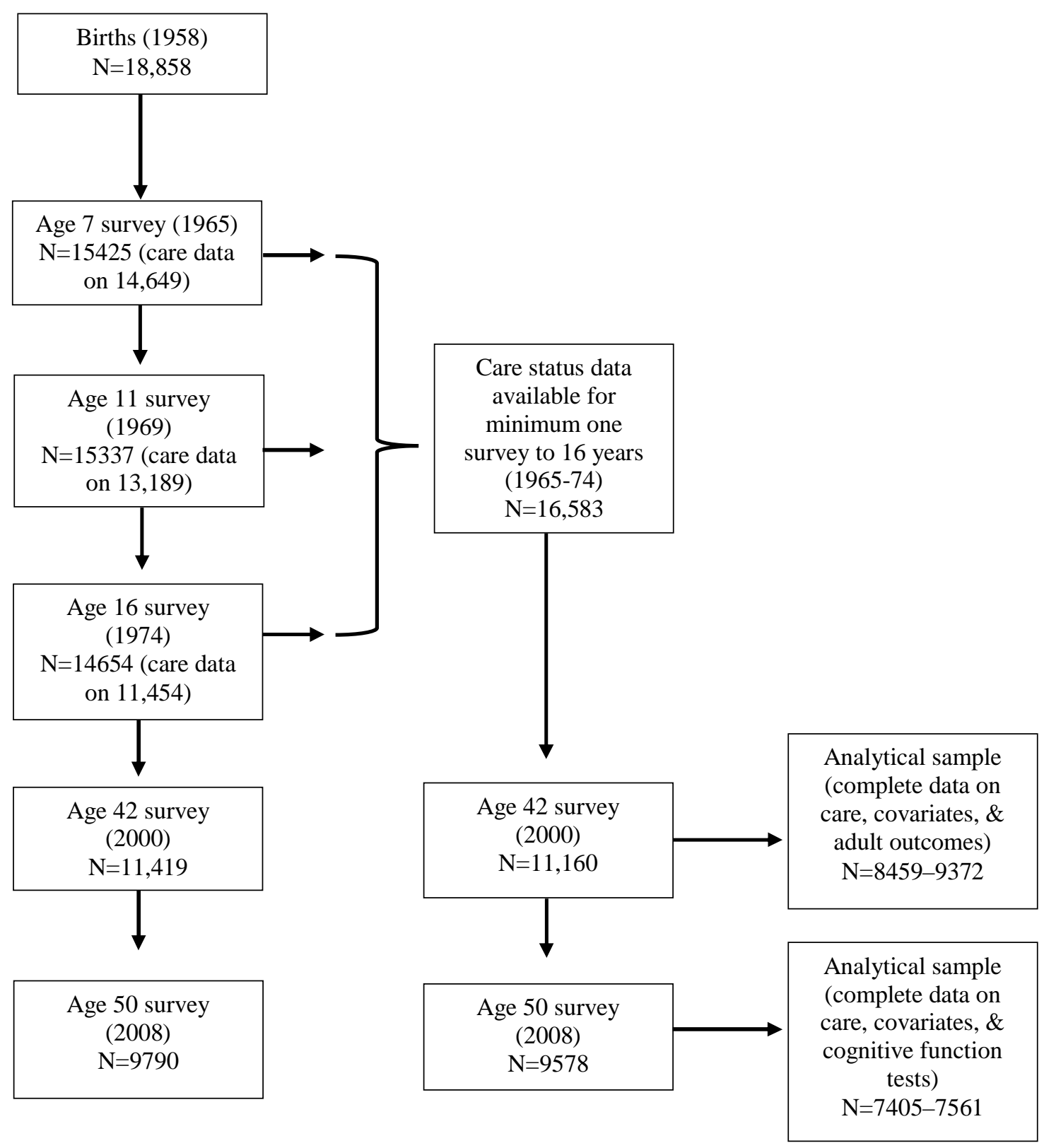


medRxiv preprint doi: https://doi.org/10.1101/2020.03.03.20030718; this version posted March 6, 2020. The copyright holder for this preprint (which was not certified by peer review) is the author/funder, who has granted medRxiv a license to display the preprint in perpetuity.

It is made available under a CC-BY 4.0 International license.

Figure 2. Multivariable adjusted association between care in childhood and outcomes at age 42 years, 1958 Birth Cohort Study
$\mathrm{N}^{\circ}$ cases $/ \mathrm{N}^{\circ}$ at risk
OR $(95 \% \mathrm{CI})$
OR $(95 \% \mathrm{CI})$

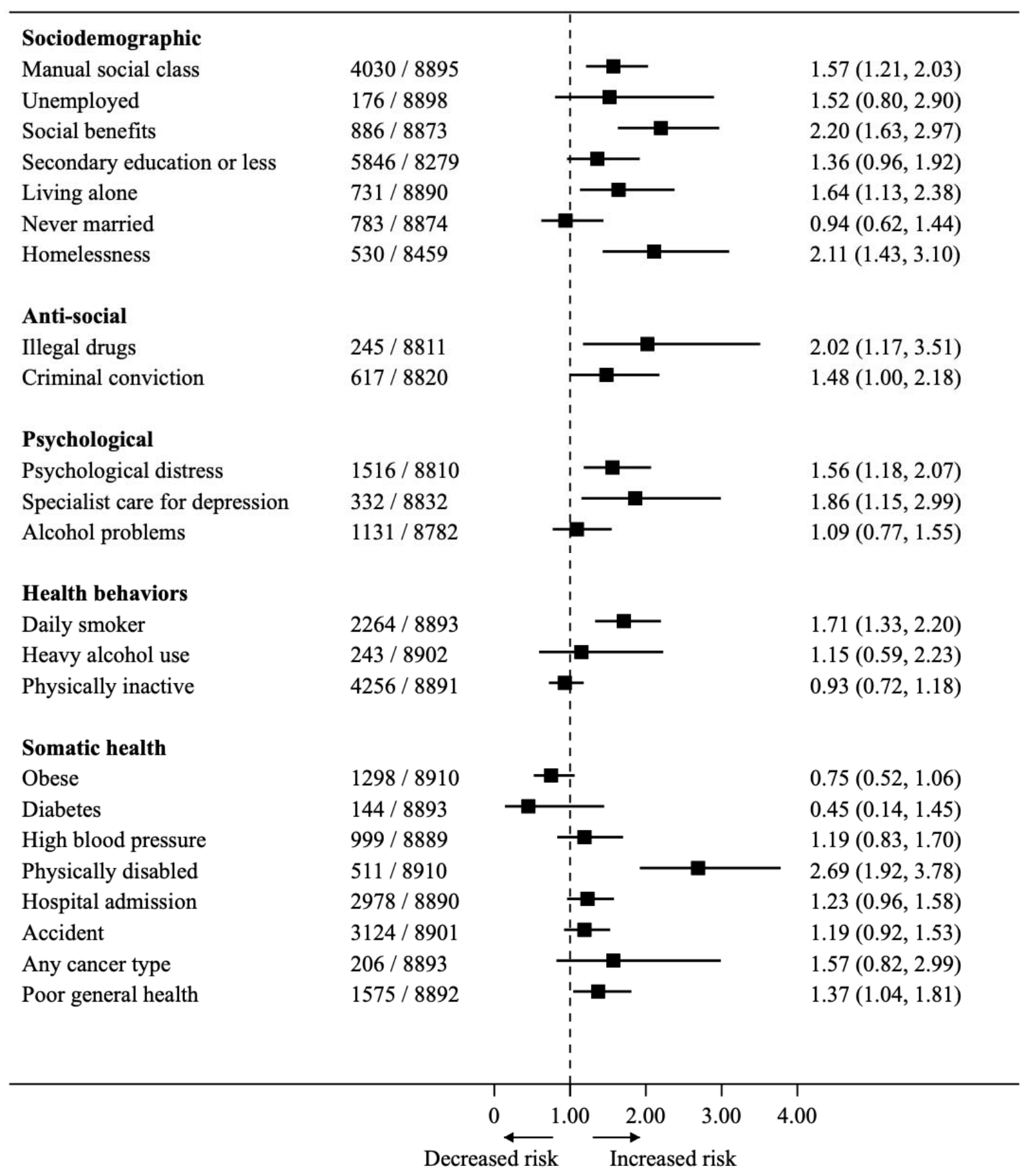

Multiply-adjusted odds ratios (OR) and 95\% confidence intervals (CI) are adjusted for the following early life factors: sex, parental social class, mother's age at birth, mother's marital status, mother's education, high number of people in household, childhood hospitalizations, childhood disability, and internalizing and externalizing symptoms. 